\title{
Policy Impact on Economic Viability of Biomass Gasification Systems in Indonesia
}

\author{
Pranpreya Sriwannawit ${ }^{* 1}$, Prashanti A. Anisa ${ }^{2}$, Ashack M. Rony ${ }^{3}$ \\ ${ }^{1}$ KTH Royal Institute of Technology, Department of Industrial Economics and Management, \\ Lindstedtsvägen 30, Stockholm, 10044, Sweden \\ ${ }^{1}$ National Science Technology and Innovation Policy Office, 31 Chamchuri Square Bldg. $14^{\text {th }}$ Fl., \\ Phayathai, Bangkok, 10330, Thailand \\ e-mail: pranpreya@sti.or.th \\ ${ }^{2}$ Indonesia Investment Coordinating Board, Directorate of Investment Licenses \\ J1. Gatot Subroto Kav.44, Jakarta, 12910, Indonesia \\ e-mail: prashanti.ti06@gmail.com \\ ${ }^{3} \mathrm{KTH}$ Royal Institute of Technology, Department of Industrial Economics and Management, \\ Lindstedtsvägen 30, Stockholm, 10044, Sweden \\ e-mail: ronykth@gmail.com
}

Cite as: Sriwannawit, P., Anisa, P. A., Rony, A. M., Policy Impact on Economic Viability of Biomass Gasification Systems in Indonesia, J. sustain. dev. energy water environ. syst., 4(1), pp 56-68, 2016, DOI: http://dx.doi.org/10.13044/j.sdewes.2016.04.0006

\begin{abstract}
Indonesia is facing challenges on the lack of electricity access in rural areas and the management of agricultural waste. The utilization of waste-to-energy technology can help in mitigating these issues. The aim of this paper is to assess the economic viability of a biomass gasification system for rural electrification by investigating its competitiveness in relation to various government supports. Financial modelling is applied to calculate Net Present Value (NPV), Internal Rate of Return $(I R R)$, and Levelized Cost of Electricity (LCOE). NPV and IRR results indicate that biomass gasification is an economically viable option when appropriate financial government supports exist. $L C O E$ result indicates that biomass gasification system is already more economically competitive compared to diesel generator even without additional support but it is less competitive compared to the national electricity grid tariff. In conclusion, the biomass gasification system is an economically viable option for rural electrification in Indonesian context.
\end{abstract}

\section{KEYWORDS}

Renewable energy, Waste management, Waste-to-energy, Gasification, Feasibility, Incentive, Subsidy.

\section{INTRODUCTION}

The United Nations' report, Our Common Future, indicated the need towards more sustainable development in which development and environment aspects have been collapsed into one single concern and both need to go hand-in-hand [1]. In a UN's strategy established in 2000, Millennium Development Goals [2], it is commonly agreed that eradicating energy poverty can lead to these goals [3]. This paper focuses on electricity access in Indonesia.

Access to electricity is one of the most important means to support the country's economic development and sustain its continued economic growth [4, 5]. Nevertheless, nearly one quarter of Indonesian population does not have access to electricity; this

\footnotetext{
* Corresponding author
} 
corresponds to 60 million inhabitants. The majority live in rural areas, far from existing national grid [6]. The need for large-scale electricity provision in rural Indonesia is evident but the power sector is facing several challenges [7]. Firstly, Indonesia's current electricity supply is dominated by subsidized fossil fuels [8]. The average cost of electricity supply (EUR 0.16/kWh) is twice of the grid tariff (EUR 0.06-0.08/kWh). This large gap is subsidized by the government [7]. Secondly, the share of renewable source in total national energy mix is very low. According to the International Energy Agency [8], almost $90 \%$ of electricity in Indonesia is generated by fossil fuels. Thirdly, there are considerable environmental issues; Indonesian government is committed to reduce $26 \%$ of greenhouse gas emissions within 2020 in order to mitigate the climate change impact [9].

Apart from the challenge in power provision, a significant increase in the amount of waste has become a common global environmental problem. Thus, a proper strategy for waste management is imperative as it is a vital part for sustainability and environmental protection [10]. An appropriate approach should minimize the amount of waste and maximize its recovery for profitable utilization [11]. At an international level, proper waste management - as one means for mitigating carbon emission - is well recognized as underlined in the Kyoto Protocol. In terms of climate change policy, the Kyoto Protocol is considered to be the most crucial driver for the utilization and diffusion of Waste-to-Energy (WtE) technology [12]. The WtE approach is the recovery of energy from materials that would be originally disposed as waste [13]. It has become an important method because it can solve two problems simultaneously. Firstly, it addresses waste management by maximizing waste recovery and eliminating environmental hazards due to landfilling. Secondly, it addresses energy security by increasing the production of energy from renewable sources and decreasing reliance on fossil fuels [12].

Due to the aforementioned importance of WtE technology and the lack of electricity access in Indonesia, electricity from biomass waste can be a viable solution. The utilization of waste from agricultural activities can contribute to the share of renewable resources in the energy sector and this will likely become an attractive substitute of fossil fuels in the future [14]. Recently, WtE technology has progressed and its characteristics have become more attractive. Nevertheless, due to its relative newness compared to older and proven technological options, its risk can delay private investment. For private sector to invest in this field, economic profit should be assured [10]. It has been identified that the high cost of implementation is the most important barrier in environmental management systems [15]. As a result, the role of public sector to attract private investment in $\mathrm{WtE}$ technology is crucial. This underlines the importance of a study investigating economic viability of biomass-to-energy technology, by incorporating the role of the government.

Thus, the aim of this paper is to assess the economic viability of biomass gasification system for rural electrification in Indonesia by investigating how government support can help improve its competitiveness. The rest of the paper comprises four sections. The next section discusses the potential of biomass residue in the Indonesian context. Materials and methods are presented in the next section. This is followed by results and discussion section where the financial modelling is analysed. Finally, the paper ends with a concluding section presenting the conclusions, implications, limitations and possibilities for future research.

\section{THE UTILIZATION OF BIOMASS RESIDUE IN INDONESIAN CONTEXT}

Biomass is among the most abundant renewable sources [16]. It is a natural energy source commonly derived from agricultural crops and residue, plantation products, and 
animal waste $[17,18]$. In the Indonesian context, there are several reasons that make biomass residue an appropriate energy option. Firstly, Indonesia is an agricultural country where agricultural products and livestock are primary commodities leaving a large amount of biomass residue [19], around 146.7 million tons per year [17]. However, this abundant waste has not been well utilized [20]. If all waste is converted to energy, it will be equivalent to 470 GJ per year [17]. Secondly, due to the large amount of biomass residue, Indonesia is facing serious waste management problems. According to the Central Statistics Agency [21], only $40 \%$ of the waste is properly managed; the rest is disposed through open burning and dumping, causing a high risk to environment and human health. Moreover, the collection and transportation of waste are important parts of waste disposal. In fact, ineffective waste collection can cause problems to local inhabitants such as undesirable odour, visual impact and other health related issues [22]. If this waste can be utilized locally instead of being disposed at the municipality level, these issues can be lessened. Thirdly, the utilization of agricultural waste for energy generation does not disrupt food supply [23]. Fourthly, the residue is available in most regions throughout Indonesia and it is also available all year-round without any dependence on daily sunlight or seasonal changes [24]. Thus, the country's abundant agricultural waste is a key asset to confirm biomass residue as a high potential energy resource in Indonesia. In this study, agriculture waste from rice crop, particularly rice husk, is used as feedstock. Hence, biomass resource in this study refers to rice crop residue. The focus is on rice residue because rice production is available throughout the country [24] and rice industry is the largest contributor of biomass residue in Indonesia [25], containing energy potential of $150 \mathrm{GJ} /$ year. Other abundant biomass residues are from rubber wood, sugar, and palm oil residues with energy potential of $120 \mathrm{GJ} / \mathrm{year}, 78$ GJ/year, and 67 GJ/year, respectively [17].

Despite the aforementioned rationale, the utilization of biomass waste in Indonesia is still very low. The estimated potential for using biomass to generate electricity is 49,810 MW but the actual installed capacity is only 3.2\% [9]. Thus, there is a large potential to increase the biomass share in power generation using WtE technology as biomass gasification systems, which are commercially available for small-scale power plants in Indonesia [26]. There are two types of biomass conversion technologies for electricity generation: direct combustion with a steam turbine and gasification with a gas engine. For small scale, the electricity generation cost of a gasification system is lower than a combustion system [27]. In this study, the focus is on rural electrification via small isolated grid or mini-grid of which the power capacity is commonly defined at 10-200 $\mathrm{kW}$ [26]. This makes the gasification system a more suitable option than the combustion system. One of the gasification technologies appropriate for rural electrification is a fixed bed gasifier. It can utilize agricultural wastes and is suitable for the scale applications with $30-500 \mathrm{~kW}$ energy requirements. This technology is suitable for village applications and is widely used in rural areas in developing countries [28].

The utilization of biomass residue not only provides renewable energy resources for electricity generation but also prospectively helps in solving some aspects of waste management problems [29]. Nevertheless, the application of WtE technology in rural areas involves high cost due to low population density. Also, rural inhabitants usually have low income and tend to have low electricity consumption, making it less attractive compared to urban areas for private investors. On the other hand, if the funding effort is only left as a responsibility for the government, with its limited budget only a little investment will occur. Hence, good collaboration between private investors and public sector is needed and the government's role is crucial in order to attract private sector to invest in the rural market $[30,31]$. It has been emphasized that the government - at the 
central as well as the local levels - is one key actor for an inclusive approach for increasing electricity access [32]. In addition, the feasibility of biomass gasification is very site-specific due to the large difference in conditions in various locations [26]. This underlines the importance for policy research in the local environment in order to provide implications that are applicable to the region of interest.

\section{METHODS}

This section explains our methods. It begins with the explanation on financial modelling which is used to quantify and analyse the economic viability. Microsoft Excel is used as a modelling tool. Then, the research process is discussed where data sources and calculation steps are elaborate.

\section{Financial modelling}

Levelized Cost of Electricity ( $L C O E)$, Net Present Value (NPV) and Internal Rate of Return (IRR) are commonly used to evaluate the economic aspects of the investment [14, 33]. $L C O E$ is a very useful tool to compare various energy technologies of different generations and cost structures. In this study, $L C O E$ for biomass gasification is compared with diesel generator and electricity grid tariff. Although $L C O E$ is very useful as a comparative calculation on a cost basis, more detailed approaches - which take into account taxes, interest payments, incentives and subsidies - are necessary in order to assess the profitability $[34,35]$. Thus, $N P V$ and $I R R$ are calculated in financial modelling based on cost and income on the basis of a cash-flow model. NPV and IRR are applicable to any economic investment that is expected to generate future profit. They are the primary tools for investment evaluation in terms of economic profitability and decision-making [36, 37]. Positive $N P V$ means that the investment is profitable; therefore, theoretically, private investors should invest when $N P V$ is positive [36]. The minimum required $I R R$ for the investment in energy sector to be profitable is assumed to be $11 \%$ [38]. NPV and IRR serve as appropriate tools and are complementary to LCOE in this study. Nevertheless, it should be noted that the variables used in this kind of research are highly volatile and the results can present a divergent outcome if the variables are modified.

\section{Research process}

This research process comprises six steps where various data sources and calculation are combined. This is summarized in Figure 1. The project feasibility should be assessed based on local conditions in the regions of interest [27]. Therefore, large parts of the data are obtained from secondary sources that specifically address rural Indonesian context. In order to answer the research aim, these data are adjusted to fit the specific context. More information on how the data are adjusted is provided in this section.

In the first step, the electricity demand of a generic village in rural Indonesia, comprising 1,475 people in 350 households, is defined. In the second step, the amount of electricity load profiles per day is defined based on the corresponding electricity demand, which equals $558.5 \mathrm{kWh}$ per day. In the third step, the required capacity of biomass power plant is defined to meet the electricity load profiles, corresponding to $69.6 \mathrm{~kW}$. The data in the first three steps are based on Blum et al. [7].

In the fourth step, the input for financial modelling is defined. The private sector will invest only if the project is profitable. Therefore, we calculate two sets of data: income from sale of electricity and cost of electricity.

The first set of data is the income from sale of electricity. Based on the data from Schmidt et al. [39], we take into account potential income streams from three levels: 
local, national and international. At the local level, the income from sale of electricity is reflected from the villager's Willingness To Pay (WTP) because it shows how much villagers are willing to pay for electricity that are sold by private investors. The result from the second step is used to further calculate the income since it is also determined by the amount of electricity sold to the villagers. WTP ranges from USD 0.12 to $0.25 / \mathrm{kWh}$ [39]. In this calculation, the middle value of USD $0.18 / \mathrm{kWh}$ is used. At the national level, the potential income comes from the re-distribution of electricity subsidy and fuel subsidy [39]. In Indonesia, the retail electricity tariff is too low to cover the cost of electricity production. Thus, the tariff system receives a significant amount of subsidies in the form of electricity subsidy and fuel subsidy $[40,41] .{ }^{\dagger}$ Since rural electrification is not included in the national grid, it does not benefit from these subsidies. In this study, these subsidies to biomass gasification power plant are reallocated to evaluate their potential impact on the income. Schmidt et al. [39] indicate that the reallocation of the electricity and fuel subsidy on biomass power plant results in additional income of USD $0.38 / \mathrm{kWh}$ and USD $0.29 / \mathrm{kWh}$, respectively. At the international level, the Clean Development Mechanism (CDM) credits of the Kyoto Protocol provide financial incentives for off-grid projects through carbon credits for renewable energy technologies that mitigate $\mathrm{CO}_{2}$ emissions [42]. Biomass power plant projects potentially reduce $\mathrm{CO}_{2}$ emissions by $0.96 \mathrm{~kg} \mathrm{CO} / \mathrm{kWh}$ [7]. The potential income from CDM is USD $0.01 / \mathrm{kWh}$ [39]. Despite the small additional incentive, CDM has been proved to positively impact the investment opportunities [43].

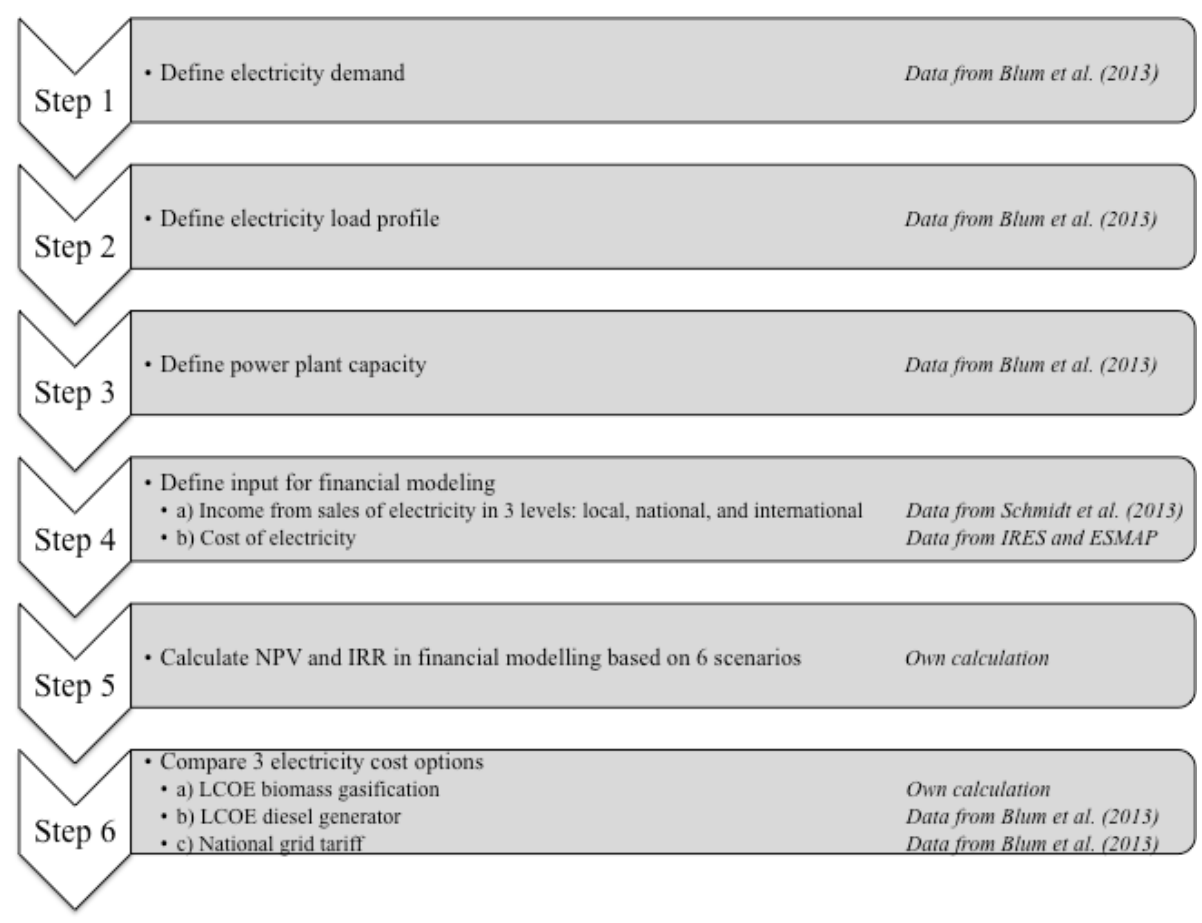

Figure 1. Overview of research process

The second set of data is the cost of electricity, which is site-specific. In the case of Indonesia, there are very few examples of biomass power plants [20] and we have not

\footnotetext{
$\dagger$ The electricity subsidy bridges the gap between the retail electricity tariff set by the government and the real cost of electricity generation, transmission, distribution and sales [7]. In addition, fossil fuels in Indonesia are heavily subsidized; local diesel prices are protected against world price fluctuation. These subsidies are applied to all electricity generated and distributed through the national grid [40].
} 
found any study that discusses the feasibility of gasification technology. Thus, we use the data obtained directly from Indonesia Renewable Energy Society (IRES) and compared with the study by Energy Sector Management Assistance Program (ESMAP) [35]. These data are also validated by consultation with an Indonesian expert in the biomass field. Based on the result from the third step, the required capacity of biomass power plant is $69.6 \mathrm{~kW}$ while the data from IRES are for biomass power plant with $1.2 \mathrm{MW}$ capacities. Therefore, an adjustment is necessary in order to determine the cost of the target capacity. Following the study by Moon et al. [27], the capital cost according to the capacity is calculated by the following expression: (Base capital investment cost) $\times$ (Target capacity/Base capacity) ${ }^{0.6}$.

In the fifth step, financial modelling is run based on two sets of data, which are derived from the fourth step. We use simulation modelling technique with alternative scenarios where various potential income possibilities are proposed (more details about these scenarios are discussed in Results and Discussion section). The impact of various policy scenarios on $N P V$ and $I R R$ of biomass power plant is analysed.

In the final step, the $L C O E$ is analysed based on the cost data from the fourth step. $\angle C O E$ of biomass gasification system from our own calculation is compared with competing options, i.e. $L C O E$ of diesel generator and electricity grid tariff set by a state-owned power company obtained from Blum et al. [7].

\section{RESULTS AND DISCUSSION}

This section discusses the results from the financial modelling, using the data about biomass gasification investment from the previous section. NPV, IRR and LCOE of biomass gasification power plant are evaluated.

\section{NPV and IRR of biomass gasification system}

Alternative scenarios in the simulation are proposed in Table 1. These scenarios compare the effects of additional potential income, besides at the local level. The additional income is from the national and international level. For scenario 1, only local income is applied, of which WTP value is used. For scenarios 2 and 3, the national income - comprising the fuel and electricity subsidies ${ }^{\ddagger}-$ are applied respectively. For scenario 4, international income - CDM credit - is applied. For scenario 5, the combination of national income - both fuel and electricity subsidies - is applied in order to show the combined effect of these two subsidies. Lastly, for scenario 6, all three types of potential income are applied to show the total combined effect. Based on these six scenarios, $N P V$ and $I R R$ of a biomass gasification power plant are calculated in the financial modelling. The results are presented in Table 2.

According to Table 2, scenarios 1-4 are not financially feasible because the results yield negative $N P V$ and $I R R$. This implies that the application of fuel subsidy, electricity subsidy and CDM can improve the competitiveness of biomass gasification; however, the application of only one policy instrument is not sufficient. Among these three additional instruments applied in scenarios 2-4, the significant effects on $N P V$ can be seen from the reallocation of fuel and electricity subsidy. Due to low carbon prices, the additional incentive from CDM only contributes to a small increase in $N P V$ value. This is in line with a previous study by Schmidt et al. [39], which argues that the application of carbon

$\$$ These two subsidies already exist for diesel generators. Since renewable energy can potentially replace diesel generators in the future [39], we reallocate diesel subsidies to biomass in our financial modelling. This is to show that when the subsidies received by the diesel generators are passed on to the biomass gasification power plants, it could generate additional income and increase $N P V$ and $I R R$ values. 
credits alone will not make rural electrification attempts economically feasible. This is assumed to be due to the huge project capital cost and operating cost compared to the income. The income from sale of electricity cannot cover the cost because electricity demand in rural areas is usually relatively low, $558.5 \mathrm{kWh}$ per day corresponding to only one-third of the electricity supply of $1,670.4 \mathrm{kWh}$ per day ${ }^{\S}$. This low electricity demand also leads to the lower utilization of biomass gasification system since not all the electricity produced will be sold to the potential consumers.

In scenario 5, where national income is applied, $N P V$ still yields a negative value but IRR becomes positive at $12.79 \%$. Despite the negative value of $N P V$, the magnitude improves almost 100 times when the result from scenario 1 is compared with scenario 5. This means that although the combination of subsidies from national income can yield a significant impact on the competitiveness, it is still not sufficient to make the investment economically viable.

In scenario 6, where all potential income is applied, biomass gasification becomes a financially viable $\mathrm{WtE}$ technology. It is the only scenario for which both $N P V$ and IRR yield positive values. This implies that, despite its small contribution in scenario 4, CDM of USD $0.01 / \mathrm{kWh}$ can play a significant role in improving the competitiveness when it is combined with other subsidies in scenario 5. The provision of national and international instruments makes scenario 6 the financially best option, yielding $N P V$ of USD 2,313 and $I R R$ of $13.06 \%$. This $I R R$ value is quite attractive to private investors, as it is above the recommended value of $11 \%$ [38]. The results suggest that the competitiveness of biomass gasification can significantly increase with intensive government support and this can attract private investment.

Table 1. List of scenarios used in financial modelling

\begin{tabular}{ccc}
\hline Scenario & Income & Formula [USD/kWh] \\
\hline 1 & Local income & 0.18 \\
2 & Local income plus fuel subsidy & $0.18+0.29$ \\
3 & Local income plus electricity subsidy & $0.18+0.38$ \\
4 & Local income plus international income & $0.18+0.01$ \\
5 & Local income plus national income & $0.18+0.29+0.38$ \\
6 & Local income plus national and & $0.18+0.29+0.38+0.01$ \\
\hline
\end{tabular}

Table 2. $N P V$ and $I R R$ of biomass gasification

\begin{tabular}{ccccccc}
\hline \multirow{2}{*}{ Parameter } & \multicolumn{6}{c}{ Scenario } \\
\cline { 2 - 7 } & 1 & 2 & 3 & 4 & 5 & 6 \\
\hline$N P V[$ USD] & $-751,369$ & $-420,192$ & $-320,883$ & $-736,616$ & $-8,167$ & 2,313 \\
$I R R[\%]$ & Negative & Negative & Negative & Negative & 12.79 & 13.06 \\
\hline
\end{tabular}

\section{LCOE of biomass gasification system}

$L C O E$ of biomass gasification system is calculated and compared with two competing options, of which the data are obtained from Blum et al. [7]. Firstly, we compare with diesel generator because it is the most common technology for electricity generation in rural Indonesia where national grid is not in existence [40]. Secondly, we compare with

${ }^{\S}$ Here, we use the assumption that electricity is produced for 24 hours at a constant rate of $69.6 \mathrm{~kW}$. 
electricity grid tariff to analyse its competitiveness in the areas that are already connected to the national grid. The comparison is summarized in Table 3. The formula for $L C O E$ calculation is as follows [44]:

$$
L C O E=\frac{I_{\mathrm{o}}+\sum_{t=1}^{n} \frac{T_{t}}{(1+r)^{t}}}{\sum_{t=1}^{n} \frac{M_{t}}{(1+r)^{t}}}
$$

where:

- $I_{0}$ - investment expenditure [USD];

- $T_{t}-$ total cost expenditure accrued throughout the system lifetime [USD];

- $M_{t}$ - produced quantity of electricity in the respective year [kWh];

- $r$-real interest rate [\%];

- $n$-economic operational lifetime [year];

- $t$ - year of lifetime $(1,2, \ldots n)$.

Table 3. Comparison of electricity cost

\begin{tabular}{cccc}
\hline Parameter & Grid tariff & $\begin{array}{c}\text { LCOE biomass } \\
\text { gasification }\end{array}$ & $\begin{array}{c}\text { LCOE diesel } \\
\text { generator }\end{array}$ \\
\hline Cost [USD cent $/ \mathrm{kWh}]$ & $7.9-11.8$ & 22.1 & 45.9 \\
\hline
\end{tabular}

According to Table 3, $L C O E$ for biomass gasification is USD cents $22.1 / \mathrm{kWh}$, only half of that for a diesel generator. This result strengthens ESMAP's study [35], which reports that $\angle C O E$ for biomass gasification project is lower than diesel generator. The reasons for high $L C O E$ for diesel are due to external factors such as transportation cost of diesel from distribution centre to local site where electricity is generated. Moreover, when no subsidies are applied to diesel generator, it is considered as an expensive option for rural electrification [7]. The result suggests that biomass gasification has a large potential to replace diesel generators in rural areas. In comparison with the electricity grid tariff, biomass $\angle C O E$ is two to three times higher. One explanation for this low electricity tariff is because Indonesian government provides subsidies to the grid tariff, which is in fact powered mostly by fossil fuels. Therefore, without additional financial support from the government, biomass gasification is not a competitive technology compared to electricity generated from the existing grid, which is currently subsidized.

\section{CONCLUSIONS}

This research conducts an economic viability assessment of a biomass gasification system for rural electrification in Indonesia. The results reveal $N P V$ and IRR yield positive values only when financial support at national and international levels exists, i.e., the reallocation of subsidies from fossil fuels to biomass, and CDM. In addition, the $\angle C O E$ of biomass gasification is only half of diesel generator but much higher than the grid tariff. Thus, even without additional government support, biomass gasification system is already more economically competitive than diesel generator but it is still not competitive compared to the electricity generated from the existing grid. The results demonstrate that intensive government support can make biomass residue become a high potential energy resource and enable biomass gasification to be an economically viable $\mathrm{WtE}$ technology for rural electrification. 
In the context of Indonesia, biomass gasification provides energy to rural communities utilizing agricultural waste. Therefore, it not only addresses energy security but also the waste management aspect. The government, however, cannot be the sole player in this process. Collaboration between the government and private sector is important. Appropriate government support can significantly improve the competitiveness of $\mathrm{WtE}$ technology and make the investment become profitable for private sector. Our finding is of particular importance for policy makers and private investors who attempt to utilize renewable resources in a rural context. As a policy implication, it may be critical for the government to encourage private investment by reallocating the existing subsidies from fossil fuels to renewable sources. As an entrepreneurial implication, the results present economic viability of biomass gasification in various scenarios, which can help private investors in decision-making. It is also recommended that local needs and specificities should be investigated prior to the investment.

Our results shed light on one policy mechanism. Nevertheless, there are some limitations that can be addressed in future research. We only analyse the effects of government incentives and subsidies. However, there are other economic aspects that can improve the competitiveness for rural application such as alternative financing schemes (e.g. 5P: Pro-Poor Public-Private Partnership) or alternative business models (e.g. micro-credit or fee-for-service). Hence, future research could integrate these economic aspects together with the policy dimension, which we have discussed in this paper, in order to provide holistic solutions for the rural community. The implementation of proper government support can benefit rural communities, promote the production of electricity from sustainable energy sources, and - at the same time - strongly mitigate waste management problem. It should be noted that our study does not consider the externalities of fossil fuels or the externalities of waste management when the biomass residue is not used for electricity generation. If these negative externalities are taken into account, the competitiveness of $\mathrm{WtE}$ technology can be enhanced even more. This aspect may be taken into account in future research for more accurate policy recommendation for biomass gasification system in comparison with other alternatives.

\section{ACKNOWLEDGEMENTS}

The earlier version of this paper has been presented and published in the Proceedings of the $9^{\text {th }}$ Conference on Sustainable Development of Energy, Water and Environment Systems (SDEWES). The authors appreciate comments from the reviewer, editor and participants of the conference. In addition, the authors thank the editor and anonymous reviewers of JSDEWES for further comments, which help improving the paper in its final stage. This work was partially supported by KTH Royal Institute of Technology, Swedish Institute Scholarship, Royal Thai Government Scholarship, and the Indonesian government.

\section{REFERENCES}

1. WCED (World Commission on Environment and Development), Our common future, 1987.

2. United Nations, Millennium Development Goals: Background, http://www.un.org/millenniumgoals/bkgd.shtml, [Accessed: 19-August-2013]

3. Brew-Hammond, A., Energy: The Missing Millennium Development Goal, In: Toth F. L., editor, Energy for Development: Resources, Technologies, Environment, London: Springer; 2012, p. 35-43, http://dx.doi.org/10.1007/978-94-007-4162-1_3 
4. Sovacool, B. K., Energy Access and Energy Security in Asia and the Pacific, Asian Development Bank Economics Working Paper Series, 2013.

5. Bazilian, M. and Pielke, R., Making Energy Access Meaningful, Issues in Science and Technology, Vol. 29, No. 4, pp 74-79, 2013.

6. IEA (International Energy Agency), World Energy Outlook 2014, Paris, 2014.

7. Blum, N. U., Wakeling, R. S. and Schmidt, T. S., Rural Electrification Through Village Grids: Assessing the Cost Competitiveness of Isolated Renewable Energy Technologies in Indonesia, Renew. Sustain. Energy. Rev., Vol. 22, pp 482-496, 2013, http://dx.doi.org/10.1016/j.rser.2013.01.049

8. IEA (International Energy Agency), Southeast Asia energy outlook, Paris, 2013.

9. Sukarna, D., The Development of New and Renewable Energy Utilization in Indonesia, The 5th Indonesia-Korea Energy Forum Presentation, South Korea, 2011.

10. Tolis, A., Rentizelas, A., Aravossis, K. and Tatsiopoulos, I., Electricity and Combined Heat and Power from Municipal Solid Waste; Theoretically Optimal Investment Decision Time and Emissions Trading Implications, Waste Management \& Research, Vol. 28, No. 11, pp 985-995, 2010, http://dx.doi.org/10.1177/0734242X10371355

11. Cucchiella, F., D'Adamo, I. and Gastaldi, M., Municipal Waste Management and Energy Recovery in an Italian Region, Waste Management \& Research, Vol. 30, No. 12, pp 1290-1298, 2012, http://dx.doi.org/10.1177/0734242X12462284

12. Sommer, M. and Ragossnig, A., Energy from Waste in Europe: An Analysis and Comparison of the EU 27, Waste Management \& Research, Vol. 29, No. 10, pp 69-77, 2011, http://dx.doi.org/10.1177/0734242X11417987

13. Kothari, R., Tyagi, V. V. and Pathak, A., Waste-to-energy: A Way from Renewable Energy Sources to Sustainable Development, Renew. Sustain. Energy. Rev., Vol. 14, No. 9, pp 3164-3170, 2010, http://dx.doi.org/10.1016/j.rser.2010.05.005

14. Hublin, A., Schneider, D. R. and Dzodan, J., Utilization of Biogas Produced by Anaerobic Digestion of Agro-industrial Waste: Energy, Economic and Environmental Effects, Waste Management \& Research, Vol. 32, No. 7, pp 626-633, 2014, http://dx.doi.org/10.1177/0734242X14539789

15. Kola-Lawal, C., Wood, M., Alo, B. and Clark, A., Factors in Organisational Environmental Management System Implementation: Developed vs. Developing Country Contexts, Journal of Sustainable Development of Energy, Water and Environment Systems, Vol. 2, No. 4, pp 408-421, 2014, http://dx.doi.org/10.13044/j.sdewes.2014.02.0032

16. Ni, M., Leung, D. Y. C., Leung, M. K. H. and Sumathy, K., An Overview of Hydrogen Production from Biomass, Fuel Processing Technology, Vol. 87, No. 5, pp 461-472, 2006, http://dx.doi.org/10.1016/j.fuproc.2005.11.003

17. Hasan, M. H., Mahlia, T. M. I. and Nur, H., A Review on Energy Scenario and Sustainable Energy in Indonesia, Renew. Sustain. Energy. Rev., Vol. 16, No. 4, pp 2316-2328, 2012, http://dx.doi.org/10.1016/j.rser.2011.12.007

18. Prakoso, T., Teknologi Konversi Bioenergi bagi Investasi Pemanfaatannya (Bioenergy Conversion Technology for Utilization of Investment), FGD Model Investasi Bioenergi (Focus Group Discussion of Bioenergy Investment Model), 2012.

19. Witjaksono, Y., Prospek Energi Terbarukan Berbasis Biomassa di Indonesia (The Potential of Biomass-Based Renewable Energy in Indonesia), 2013.

20. Rufaida, A., Pengembangan Pembangkit Listrik Berbasis Biomassa di Indonesia (Development of Biomass Based Power Plant in Indonesia), Temu Karya Pengembangan Biomassa Perkebunan untuk Energi Terbarukan (Gathering of Biomass Plantation Development for Renewable Energy), Pekanbaru, 2013. 
21. Sanitasi (Dasar-Dasar sistem pengelolaan sampah (The Basics of Waste Management System)),

http://www.sanitasi.or.id/ppsp/wpcontent/uploads/pdf/persampahan/materi1/4_dasar dasar_sistem_pengelolaan_sampah.pdf, [Accessed: 15-April-2014]

22. Teixeira, C. A., Russo, M., Matos, C. and Bentes, I., Evaluation of Operational, Economic and Environmental Performance of Mixed and Selective Collection of Municipal Solid Waste: Porto Case Study, Waste Management \& Research, Vol. 32, No. 12, pp 1210-1218, 2014.

23. Lim, J. S., Manan, Z. A., Alwi, S. R. W. and Hashim, H., A Review on Utilisation of Biomass from Rice Industry as a Source of Renewable Energy, Renew. Sustain. Energy. Rev., Vol. 16, No. 5, pp 3084-3094, 2012, http://dx.doi.org/10.1016/j.rser.2012.02.051

24. Ministry of Agriculture Republic of Indonesia, http://www.pertanian.go.id/, [Accessed: 15-April-2014]

25. Hambali, E., Thahar, A. and Komarudin, A., The Potential of Oil Palm and Rice Biomass as Bioenergy Feedstock, 7th Biomass Asia Workshop, Jakarta, Indonesia, 2010.

26. Siemons, R. V., Identifying a Role for Biomass Gasification in Rural Electrification in Developing Countries: The Economic Perspective, Biomass and Bioenergy, Vol. 20, No. 4, pp 271-285, 2001, http://dx.doi.org/10.1016/S0961-9534(00)00085-4

27. Moon, J. H., Lee, J. W. and Lee, U. D., Economic Analysis of Biomass Power Generation Schemes under Renewable Energy Initiative with Renewable Portfolio Standards (RPS) in Korea, Bioresource Technology, Vol. 102, No. 20, pp 9550-9557, 2011, http://dx.doi.org/10.1016/j.biortech.2011.07.041

28. Onchieku, J. M., Odongo, F., Ondieki, M. M. C., Gladys, K. M., Mayaka, A., Wanjiku, J. and Chiteva, R., Biomass Gasification and Technology Utilization, Proceedings of Biomass Gasification Workshop, Wida Highway Motel, Kenya, 2011.

29. Carlos, R. M. and Khang, D. B., Characterization of Biomass Energy Projects in Southeast Asia, Biomass and Bioenergy, Vol. 32, No. 6, pp 525-532, 2008, http://dx.doi.org/10.1016/j.biombioe.2007.11.005

30. The World Bank, Designing sustainable off-grid rural electrification projects: Principles and practices, Washington DC, 2008.

31. Barnes, D. F. and Floor, W. M., Rural Energy in Developing Countries: A Challenge for Economic Development, Annu. Rev. Energ. Environ., Vol. 21, No., pp 497-530, 1996, http://dx.doi.org/10.1146/annurev.energy.21.1.497

32. Gomez, M. F., Sanches-Pereira, A. and Silveira, S., Technology for Social Inclusion: The Case of Electricity Access in the Brazilian Amazon, Journal of Sustainable Development of Energy, Water and Environment Systems, Vol. 1, No. 3, pp 237-259, 2013, http://dx.doi.org/10.13044/j.sdewes.2013.01.0018

33. Bazilian, M., Onyeji, I., Liebreich, M., MacGill, I., Chase, J., Shah, J., Gielen, D., Arent, D., Landfear, D. and Zhengrong, S., Re-considering the Economics of Photovoltaic Power, Renew. Energ., Vol. 53, pp 329-338, 2013, http://dx.doi.org/10.1016/j.renene.2012.11.029

34. IRENA (International Renewable Energy Agency), Cost analysis of biomass for power generation, Abu Dhabi, 2012.

35. ESMAP (Energy Sector Management Assistance Program), Technical and economic assessment of off-grid, mini-grid and grid electrification technologies, Washington DC, 2007.

36. Gapenski, L. C., A Better Approach to Internal Rate of Return, Healthcare Financial Management, Vol. 43, No. 4, pp 93-94, 1989. 
37. Delivand, M. K., Barz, M. and Gheewala, S. H., Logistics Cost Analysis of Rice Straw for Biomass Power Generation in Thailand, Energy, Vol. 36, No. 3, pp 1435-1441, 2011, http://dx.doi.org/10.1016/j.energy.2011.01.026

38. Delivand, M. K., Barz, M., Gheewala, S. H. and Sajjakulnukit, B., Economic Feasibility Assessment of Rice Straw Utilization for Electricity Generating through Combustion in Thailand, Applied Energy, Vol. 88, No. 11, pp 3651-3658, 2011, http://dx.doi.org/10.1016/j.apenergy.2011.04.001

39. Schmidt, T. S., Blum, N. U. and Wakeling, R. S., Attracting Private Investments into Rural Electrification: A Case Study on Renewable Energy Based Village Grids in Indonesia, Energy. Sustain. Dev., Vol. 17, No. 6, pp 581-595, 2013, http://dx.doi.org/10.1016/j.esd.2013.10.001

40. Differ Group, The Indonesian electricity system: A brief overview, 2012.

41. Braithwaite, D., Chandra, A., Diah, P., Indriyanto, A., Lang, K., Lontoh, L., Siahaan, N., Vis-Dunbar, D., Wattimena, B. A., Widhiantoro, U. and Wooders, P., Indonesia's Fuel Subsidies: Action Plan for Reform, The International Institute for Sustainable Development, 2012.

42. IEA (International Energy Agency), Advantage energy: Emerging economies, developing countries and the private-public sector interface, Paris, 2011.

43. Tang, A. and Taylor, J. E., Renewable Energy Investment in Emerging Markets: Evaluating Improvements to the Clean Development Mechanism, Journal of Sustainable Development of Energy, Water and Environment Systems, Vol. 2, No. 2, pp 152-173, 2014, http://dx.doi.org/10.13044/j.sdewes.2014.02.0014

44. Fraunhofer Institute for Solar Energy Systems ISE, Levelized cost of electricity: Renewable energy technologies, 2013. 


\section{APPENDIX: Assumptions for power generation capacities}

Table A1. Biomass gasification power plant $100 \mathrm{~kW}$ key assumptions

\begin{tabular}{lc}
\hline 1. Cost of project [USD] & \\
Plant investment & \\
Pre-development cost & 9,000 \\
Land & 38,000 \\
Power generation facilities & \\
$\quad$ Civil & 194,000 \\
$\quad$ Construction \& commissioning & 130,000 \\
$\quad$ Engineering & 52,000 \\
$\quad$ Mechanical, electrical, instrument equipment & 363,000 \\
$\quad$ Contingencies & 24,000 \\
Total project cost & 810,000 \\
2. Bank financing [USD] & 567,000 \\
3. Annual production [kWh] & \\
Installed capacity [kW] & 100 \\
Internal usage [kW] & 15 \\
Available capacity [kW] & 85 \\
Capacity factor & $82 \%$ \\
$\quad$ Net capacity [kWh/year] & $203,852.5$ \\
4. Electricity price/kWh [USD cents] & 18 \\
5. Feedstock cost/kWh [USD cents] & 3.5 \\
$\quad$ Plant heat rate [kcal/kWh] & 5,000 \\
Fuel caloric value [kg/Kcal] & 3,425 \\
Rice husk waste consumption [kg/kWh] & 1.46 \\
Rice husk waste price [USD/kg] & 0.024 \\
6. Fixed O\&M cost [USD cents/kWh[ & 0.35 \\
7. Variable O\&M cost [USD cents/kWh] & 1.6 \\
8. Distribution cost [USD cents/kWh] & 1.48 \\
9. Bank Interest Rate (IDR) & $13 \%$ \\
10. Corporate income tax & $30 \%$ \\
\hline
\end{tabular}

